\title{
The Annals of Iowa, 1947-1992 and Beyond: An Editor's Reflections
}

\section{MARVIN BERGMAN}

FOR THE PAST SEVERAL YEARS, whenever the demands of producing the quarterly issues of the Annals of Iowa have allowed us to pursue other tasks, my student assistants and I have been compiling a cumulative index for the journal. That index is-at last-complete. ${ }^{1}$ The task of compiling the index has been long and often tedious; I have had many occasions to resent its presence cluttering my desk and interfering with more pressing work. Yet at the same time it has been an illuminating experience: I now know more about the Annals of Iowa and its past than I ever have before. As I checked the innumerable names of the settlers of Colesburg or Perry, or tried to find the first names of Civil War officers or wives of nineteenth-century legislators, or rethought the subject headings for social history articles, I was moved to reflect on the significant changes the Annals has undergone over the years

1. The index is available for purchase for $\$ 14.95$ from our publications sales office (State Historical Society of Iowa, 402 Iowa Ave., lowa City, IA 52240 , or call (319)/335-3912. This cumulative index covers volumes 29-50 (July 1947-Spring 1991). It is only the fourth cumulative index published for the journal. The first index covered volumes 1-8 of the third series (April 1893-January 1909); the second covered volumes 9-16 (April 1909-April 1929); and the third covered volumes 17-28 (July 1929-April 1947). Copies of the second and third indexes are still available. In the current index, articles are indexed by author, title, and subject, including names; book reviews are indexed by title, author, and reviewer but not by subject. With no cumulative index available for the years since 1947, this index is obviously long overdue. It should be an invaluable tool for genealogists and other historical researchers.

THE ANNALS OF IOWA 52 (Winter 1993). (CThe State Historical Society of Iowa, 1993. 
since the last cumulative index was published in 1947, as well as to consider where it should go from here.

The Annals of Iowa has become a respected journal among professional historians. It treats a wide range of topics from state-level political history to local social history. Its authors generally have a dynamic view of the past as a time out of which the present emerged through a pattern of continuity and change that needs to be explained. It was not always so. The present Annals is the product of a revolutionary change in 1972 followed by a series of more evolutionary changes. Prior to 1972, the Annals reflected a quite different view of the past, a view that in hindsight appears narrow and static.

IN THE POSTWAR YEARS, under the editorship of Emory English, the Annals published many articles on pioneer history, nineteenth-century politics and politicians, and, less predictably, judges and the judicial system. Unlike subsequent editors, English himself was a regular contributor. Many of the articles on politics and politicians-most notably, perhaps, the "Eminent Iowans" series-remain useful for reference purposes. On the other hand, much of the pioneer history displays a now embarrassingly ethnocentric attitude toward the native inhabitants of the area that was to become the state of Iowa. Apart from that implicitly interpretive bias, most of the articles from those years-even the most useful among them-were long on facts and short on interpretation.

In the late 1950s the Annals published a steadily increasing number of idiosyncratic, often nostalgic, articles along with a continuing diet of nineteenth-century politics. Many of the oddities were little more than "fillers": "Mormon Girl Stopped Indian Attack," "Iowan Suggested Memorial Day," "Good Shooting," "Snakes in Madison County." Some, including my favorite, "Hunting Methodists Kill 1,600 Pounds of Buffalo Meat in Kossuth County," were mere reprints of old newspaper articles. Others, however, were full-fledged articles: my assistant's favorite in this category is "The Autobiography of an Old House." That article, which took up 125 pages over three consecutive issues of the journal, actually represented the house of a state legislator's family speaking 
in the first person in a lyrical, excessively romantic voice about events that it had "witnessed." The opening line captures the spirit of the past that so often appeared in the pages of the Annals. "I am an old, old house," it began. "I belong to an age that has ended, to a day that is no more."

With the centennial of the Civil War in the early 1960s, the pages of the Annals, like those of many state historical journals, became dominated by articles spelling out in detail Iowa's role in that conflict. Some diaries were reproduced, including at least one of a woman's homefront experience, but military history predominated, with several detailed accounts of notable battles by Edwin Bearss, a research historian for the National Park Service and prolific author of Civil War military history. The appearance in the annual indexes of the names of countless Civil War soldiers, often without first names, attests to the continued prominence, if not dominance, of Civil War history for the rest of the decade.

Throughout the 1950s and 1960s, the Annals of Iowa was published in Des Moines by the lowa State Department of History and Archives, as it had been since the third series of the journal was launched in 1893. Meanwhile, the State Historical Society of Iowa in Iowa City published the Palimpsest, a popular history magazine, and the Iowa Journal of History, a highly respected journal that consistently published articles meeting the highest scholarly standards of the day. When the lowa Journal of History discontinued publication in 1961, the Annals had the opportunity to publish some of the first-rate material that might otherwise have appeared in the lowa Journal. ${ }^{2}$ William Cumberland's "The Red Flag Comes to Iowa" (1968), Morton Rosenberg's "The People of Iowa on the Eve of the Civil War" (1967), and James Connor's "The Antislav-

2. For an informative and insightful review of the history of publications of the State Historical Society of Iowa, see Alan M. Schroder, History, Analysis, and Recommendations Concerning the Public Programs of the Iowa State Historical Department, Division of the State Historical Society (Iowa City, 1981), 20-23, 51-67, 87-96, 114-18, 146-61. Unfortunately, his review covers only the Iowa City publications, so the Annals of Iowa, third series, is not included, though the first and second series are (the first series began in 1863; the second in 1882; the third in 1893). The State Historical Society of Iowa and the Iowa State Historical Department were united under a single administration in 1982. 
ery Movement in Iowa" (1970), for example, represented real contributions to scholarship on the topics they treated. Such contributions stood as exceptions to the general run of articles in the Annals during the late sixties, however.

From the late 1940s to the early 1970s, the Annals of lowa presented a view of the past represented, if in excess, by "The Autobiography of an Old House." History amounted to fixed memories of bygone days, radically disconnected from the present. Like exhibits in the state historical museum during those years, history was a lot of "old stuff." That "old stuff," too, was usually relevant only when it related to pioneer settlers or prominent (white male) Iowans. The three editors who have served the Annals since 1972 have offered a quite different view of history to their readers.

THE FIRST ISSUE edited by Judith Gildner in the fall of 1972 marked a significant shift for the Annals. An article by Wayne Fuller, "Rural Free Delivery in Hardin County," and one by Bernard Mergen, "A Quantitative Study of Wage Workers in Iowa, 1894," signaled a receptiveness to new scholarly topics and approaches. The other two articles in that issue-a "case study" of an Iowa railroad by Donovan Hofsommer and a study of Herbert Hoover and the National Credit Corporation-were more sophisticated methodologically than Annals readers would normally have expected. With the next issue, Gildner inaugurated a section devoted to "Book and Film News." By 1975 it had evolved into a fullfledged book review section.

Perhaps the most notable development during the 1970s was the recognition of women as actors in Iowa history. In previous years, indexes rarely carried women's first names. Instead, they were listed with their husbands' names, with "Mrs." attached, or they were simply included implicitly in an entry such as "the Smith family." This created agonizing decisions for compilers of a cumulative index in the early 1990s. How much time could we justify spending in an often futile effort to find these women's first names? Should we index them by maiden name or married name or both? Should we include them at all if they were there as mere appendages of their prominent husbands? By the mid-seventies, women had 
not only claimed their names, they had become subjectsand even authors-of feature articles in the Annals. In addition to articles about prominent women such as Amelia Bloomer, Annie Savery, and Mary Newbury Adams, there was a particularly noteworthy informal series of women's diaries edited by Glenda Riley.

As with Judith Gildner's first issue, a new topic-raceentered the lexicon of Iowa history when the first issue appeared under Christie Dailey's editorship in 1980. That issue featured articles on the NAACP in Des Moines and black disaffection from the Republican party during Herbert Hoover's presidency. The culmination of the treatment of this topic came with a remarkable exchange in 1984 between Hubert Wubben and Robert Dykstra on black suffrage.

The range of topics continued to expand. Carlos Schwantes's two-part article on Kelly's Army and Wilson Warren's article on welfare capitalism at John Morrell and Company added class to race and gender as a significant component of Iowa history. An occasional essay of a different sort indicated that the study of Iowa history had come into its own as a topic worthy of analysis in itself. Alan Schroder wrote "A History of Iowa Histories" and surveyed "Two Decades of Doctoral Research in Iowa History, 1961-1980." Joseph Wall analyzed the writings of Iowa's "pioneer historians" - those who wrote and edited the Annals of Iowa before 1900. Tom Morain offered "a personal essay" on how he came to "an appreciation of Iowa local history." And Stephen Cox offered suggestions on "How to Write History." At the same time, prominent twentieth-century politicians, such as Herbert Hoover, Smith Brookhart, and even Bourke Hickenlooper, received their due; and an entire, invaluable special expanded issue was devoted to Henry A. Wallace.

Clearly, I view the changes in the journal's focus under its previous two editors as positive. I have tried to build on their efforts to make the Annals reflect more of the diversity of life in Iowa. Without denying the importance of Iowa's image as a rural, agricultural state, the Annals in recent years has called attention to Iowa's urban history, most notably in a special double issue devoted to Iowa's often neglected urban center in the west, Sioux City, and in a couple of significant 
articles by Maureen Ogle on the development of water systems and fire departments in Boone, Iowa City, and Marshalltown. The underside of Iowa history appeared in articles on prostitution, a vigilante-like response to farm thieves, and the Girls Reform School of Iowa. One article even provided invaluable historical perspective on one of the most controversial social issues of recent decades: abortion.

Perhaps even more than my predecessors, I have pushed authors to interpret the facts they uncover in their research in the light of findings by other researchers who have written about related developments in other places. That emphasis on a heightened understanding of broader themes in state and local history research is also reflected in a further broadened and strengthened book review section. Unlike many editors, who farm out the book review section to a separate review editor, I see its supervision as an integral, important, and rewarding part of my editorial work on the journal. That interest culminated just this past summer in a book forum on William Cronon's important new book, Nature's Metropolis.

Academic history journals are often criticized because they fail to engage general readers; scholars simply talk to each other. In many ways, the forum on Nature's Metropolis epitomizes that tendency. Yet I have received thus far a unanimously (if limited) positive response to the forum from scholar and nonscholar alike. The latter tell me they appreciate the opportunity to be let in on the conversations that help shape the interpretations of our past. That is my goal for the Annals: to make it a place of conversation for those who are seriously interested in interpreting the causes and meaning of change and continuity in the history of Iowa and the Midwest. If that conversation is lively enough, I am confident that readers who do not have the luxury of pursuing research at the same level will find much to stimulate their understanding of their heritage and their neighbor's. To that end, I am interested particularly in organizing forums on other issues or books that would appeal to a range of interests. Unfortunately, I am short on ideas. If you have suggestions, please pass them along. 
COMPILING THE CUMULATIVE INDEX for the Annals reinforced my sense that the journal has not only changed; it has improved over the years. Nor were the changes merely products of a natural evolutionary process. To be sure, many of the changes reflect general trends in the field of American history and its publications. But the editors have made conscious choices to adopt those trends. Most of the evidence for that is hidden from or goes unnoticed by most readers. For example, the Annals added a board of respected and knowledgeable editorial consultants and became a refereed journal, as the editors turned to outside readers for advice on manuscript submissions. The State Historical Society has also supported the editors' travel to academic conferences to hear presentations of the latest research and to engage in formal and informal discussions with scholars and other editors. Those activities and others have madelthe editors more conscious of the demands of contemporary scholarship and scholarly publications, which they in turn have applied to the journal. The Annals also underwent several design overhauls in the 1970s-and a more modest one in 1989-as it approached the standard look and content of the traditional scholarly history journal.

Yet progress never comes without some costs. Even though there is no place for such pieces as "Hunting Methodists Kill 1,600 Pounds of Buffalo Meat in Kossuth County" or "The Autobiography of an Old House" in a journal that takes itself as seriously as the Annals now does, those pieces have a certain charm that some readers may miss. On the other hand, the "just the facts" tone of the articles on politics that appeared simultaneously makes them valuable as reference points in ways that today's more focused, interpretive pieces usually cannot be, while the "I was there" memoirs and reminiscences lend an immediacy to history that is now generally missing. Most of all, though, I miss the obituaries of prominent Iowans that ended each issue of the journal until 1962. They would be out of place in the current version of the journal, but our librarians have long pointed out to me the obituaries' usefulness, and I discovered what they meant as I edited the index. In general, the antiquarian appeal of the Annals from 1947 to 1972 served an audience that none of 
the society's publications or exhibits adequately serves today, even though we are often reminded that such an audience still exists.

I also miss some features from more recent years as well as some things that have never really been there. From the Judith Gildner years I miss the poetry and the focus on literature and the arts that she brought to the journal. I also have to say, as one who was trained as a religious historian and retains an abiding interest in the subject, I long for the return of religious history to the pages of the Annals. It is one of my major disappointments that despite my training and interest I have not been able in six years to attract a publishable manuscript in this area. Finally, the Annals has never done a very good job of treating Iowa's material culture, and it still doesn't ("The Autobiography of an Old House" is no exception). We need people to take a serious look at Iowa's natural and built environment and interpret for readers how aspects of it have shaped human actions as well as how human actions have shaped it.

You, the readers of the Annals of Iowa, can contribute to the journal's future growth. You can send me your comments-positive or negative. I hear far too little from you and would love to hear more, if only to know that you are out there reading. I also need your help in identifying people who can add depth or nuance to previously treated topics in Iowa history, or contribute to the expanding range of subjects I have discussed in this essay. ${ }^{3}$ If you know of anyone, including yourself, who you think might make a significant contribution to the conversation that takes place in these pages, please let me know.

In 1984 Iowa historian Joseph Wall pleaded with the State Historical Society of Iowa to give the Annals enough support for it to become "what the Iowa Journal [of History] once was." State and local history has undergone so many

3. The recently completed cumulative index, along with lowa History and Culture: A Bibliography of Materials Published Between 1952 and 1986, compiled by Patricia Dawson and David Hudson, which the State Historical Society of Iowa and Iowa State University Press copublished in 1989, are good places to find out what has been done. 
changes in the decades since the Iowa Journal was in its heyday that it is hard to know how one would measure progress toward such a goal. But I believe that the Annals, with strong support from the State Historical Society of Iowa, has earned a place of respect as a reliable source of scholarship interpreting the history of Iowa and the Midwest. Clearly, the Annals of Iowa has made marked improvements in recent decades; I invite you to help us advance it along the path that recent editors have staked out. 
Copyright of Annals of Iowa is the property of State of Iowa, by \& through the State Historical Society of Iowa and its content may not be copied or emailed to multiple sites or posted to a listserv without the copyright holder's express written permission. However, users may print, download, or email articles for individual use. 